\title{
ANALISIS PERBANDINGAN MESIN RENDER REDSHIFT, ARNOLD RENDERER, MAYA HARDWARE 2.0 PADA SHOT INDOOR DAN OUTDOOR DI DALAM KONDISI SIANG DAN MALAM PADA ANIMASI 3D "Telat"
}

\author{
Hasil Bangun Taras Barus ${ }^{1}$, Riwinoto ${ }^{2}$ \\ Informatics Engineering, Batam State Polytechnic Multimedia and Network Engineering, Batam State Polytechnic \\ Email : hasilbarus@gmail.com, riwi@polibatam.ac.id
}

\begin{tabular}{l}
\hline \hline Article Info \\
\hline Article history: \\
Received Jun $12^{\text {th }}, 2021$ \\
Revised Jun $20^{\text {th }}, 2021$ \\
Accepted Jul $26^{\text {th }}, 2021$ \\
\end{tabular}

\section{Keyword:}

Animasi

3D

Animation

Rendering

Redshift

Arnold Renderer Maya

Hardware 2.0

\begin{abstract}
Perkembangan teknologi komputer grafis di Indonesia terus berkembang khususnya di industri perfilman animasi 3D. Pada proses pembuatan film animasi 3D terdapat beberapa tahapan yang harus dilakukan yaitu, Modelling, Texturing, Rigging, Animating, Lighting Setup, dan Rendering. Pada tahapan rendering sering kali ditemukan masalah waktu dan kualitas yang dihasilkan pada setiap mesin render yang ada karena tiap mesin render memiliki pengaruh yang besar terhadap waktu dan kualitas yang dihasilkan. Mengingat pentingnya pemilihan mesin render yang tepat dalam proses produksi film animasi 3D maka perlu dilakukan penelitian untuk mengetahui mesin render dengan kualitas gambar terbaik dan mesin render dengan waktu render yang paling cepat dengan menggunakan situasi dan kondisi yang berbeda yaitu situasi indoor dan outdoor di dalam kondisi siang dan malam. Penelitian dilakukan dengan melakukan render pada 3 mesin render yaitu redshift, Arnold Renderer, dan Maya Hardware 2.0 pada film animasi 3D "Telat" sebanyak 10\% dari total keseluruhan shot. Lalu membandingkan hasilnya dengan menggunakan Teknik Sampling. Kemudian melakukan analisis terhadap masing-masing hasil render dengan mengacu pada standar kelayakan grafik/visual untuk film animasi dari perbandingan ketiga mesin render yang ditentukan oleh perusahaan animasi PT. Kinema Systrans Multimedia. Hasil penelitian yang didapat dari merender Film animasi 3D yang berjudul "Telat" dengan membandingkan pada serial animasi 3D yang berjudul "Ollie and Friends season 5", mesin render Redshift menghasilkan kualitas noise yang paling bagus pada semua kondisi. Untuk mesin render Maya Hardware 2.0 menghasilkan waktu render yang lebih cepat namun kualitas noise pada gambar berkurang. Jadi untuk menghasilkan kualitas noise yang bagus diperlukan waktu render yang cukup lama.
\end{abstract}

\section{PENDAHULUAN}

Pada proses pembuatan animasi 3D terdapat beberapa tahapan yaitu modelling, texturing, rigging, animating, Lighting, compositing dan rendering. Beberapa tahapan tersebut salah satunya terdapat masalah kompleks yang sampai saat ini masih menjadi pengamatan yaitu pada saat tahapan rendering. Rendering animasi merupakan proses pengubahan gambar yang masih berupa vector dalam beberapa gambar objek 3D yang sudah dibuat sebelumnya, lalu diurutkan dan kemudian digabungkan sehingga menghasilkan sebuah animasi 3D.

Problematika yang utama dalam melakukan proses render adalah durasi yang dibutuhkan oleh $C P U$ untuk melakukan proses rendering [2]. Tentu saja durasi yang dibutuhkan akan cukup lama apabila tidak mengetahui konsep dasar dari proses rendering. Proses rendering ini tidak hanya memproses per- model, bahkan pada dasarnya akan dilakukan sampai ke permukaan polygon [1]. Dengan demikian, semakin banyak polygon yang digunakan, proses rendering akan semakin lambat.

Untuk mengatasi permasalahan dalam pemilihan mesin render yang baik dalam kecepatan waktu dan kualitas gambar maka, Penulis melakukan sebuah penelitian yang menyajikan data hasil render dengan melakukan sampling sebanyak masing-masing dua shot indoor pada kondisi siang hari, dua shot indoor pada kondisi malam 
hari, dan dua shot outdoor pada kondisi siang hari, dua shot outdoor pada kondisi malam hari. Pada film animasi 3D "Telat". Adapun judul yang akan diteliti oleh penulis adalah "Analisa perbandingan mesin render Redshift, Arnold, Maya Hardware 2.0 pada shot indoor dan outdoor di dalam kondisi siang dan malam pada film animasi 3D "Telat"".

\section{ANALISA SISTEM}

\subsection{Waktu Render}

Pada pembuatan film animasi 3D, rendering merupakan salah satu bagian terpenting. Rendering merupakan suatu proses untuk menghasilkan gambar akhir yang kemudian akan dijadikan dalam bentuk video atau film. Pada pembuatan film animasi 3D, waktu akan mempengaruhi efisien pengerjaan film animasi itu sendiri. Semakin cepat waktu yang dibutuhkan pada proses render maka akan lebih baik.

\subsection{Kualitas Video}

Berbeda dengan kecepatan waktu yang dibutuhkan, namun hasil kualitas dari video juga menjadi pertimbangan pada hasil akhir film animasi 3D. Waktu render yang cepat tidak selalu menghasilkan kualitas video buruk, namun waktu render yang lambat pun juga tidak selamanya menghasilkan kualitas video yang baik.

\subsection{Analisis \& Pengujian}

\subsubsection{Analisis}

Analisa yang akan dilakukan oleh penulis menggunaka metode statistik deskriptif. Statistika deskriptif adalah metode statistika yang digunakan untuk menggambarkan atau mendeskripsikan data yang telah dikumpulkan menjadi sebuah informasi. (Purwanto S.K., 2012).

Pada pengujian kualitas gambar yang dihasilkan menggunakan engine render Redshift, Arnold Renderer, dan Maya Hardware 2.0 menggunakan metode deskriptif kualitatif yang mana jumlah responden ditentukan oleh penulis untuk pengujian nya. Karena pada metode kualitatif sampling dilakukan dengan metode non representative, berbeda dengan penelitian kuantitatif yang dengan cakupan lebih luas dengan jumlah responden yang jauh lebih banyak sampelnya bersifat representatif (perwakilan) yang didapatkan dengan memakai rumus, persentase atau tabel-populasi-sampel serta telah ditentukan sebelum pengumpulan data.

\subsubsection{Pengujian}

Pengujian yang dilakukan adalah pengujian kualitas noise gambar dan estimasi waktu yang dihasilkan dari engine render Redshift, Arnold Renderer, dan Maya Hardware 2.0 pada film animasi "Telat". Pengujian dan pengambilan data dilakukan dengan menggunakan komputer yang sama, proses rendering dilakukan dengan bergantian dimana tiap satu mesin render merender 4 scene dengan menggunakan engine render Redshift, Arnold Renderer, dan Maya Hardware 2.0.

Data yang diambil pada pengujian ini adalah render time dan kualitas noise gambar tiap shot pada engine render Redshift, Arnold Renderer, dan Maya Hardware 2.0. Pengujian Render time digunakan untuk mengetahui perbandingan waktu antara Redshift, Arnold Renderer, dan Maya Hardware 2.0 untuk mencari waktu tercepat dan terbaik dengan menggunakan standar deviasi.

Rumus variansi :

$$
\boldsymbol{\sigma}^{2}=\frac{\sum\left(\mathbf{x}_{\mathrm{i}}-\overline{\mathbf{x}}\right)^{2}}{\mathbf{n}}
$$

Sedangkan rumus standar deviansinya :

$$
\sigma=\sqrt{\frac{\sum\left(\mathbf{x}_{\mathbf{i}}-\overline{\mathbf{x}}\right)^{2}}{\mathrm{n}}}
$$

Dimana : 


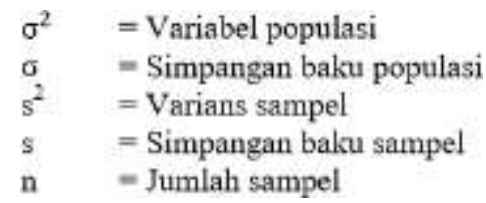

Sedangkan untuk penilaian kualitas noise pada gambar dilakukan dengan memberikan kuesioner kepada responden untuk menilai kualitas ketiga mesin render dengan bobot nilai 1 sampai 10 .

\section{HASIL DAN PEMBAHASAN}

1. Hasil Pengujian Render Time

Berikut merupakan tabel hasil pengujian render time dari proses rendering menggunakan Redshift, Arnold Renderer, dan Maya Hardware 2.0 pada film animasi 3D "Telat". Data render time dihasilkan dengan memantau rentang waktu setiap memulai proses render dan setelah proses render complete.

Setelah hasil terkumpul, selanjutnya data di sajikan ke dalam bentuk table dan dikonversikan ke dalam tabel grafik. Berikut hasil pengujian render time indoor dari scene beserta hasil konversi nya pada siang hari seperti pada gambar 1 dibawah ini.

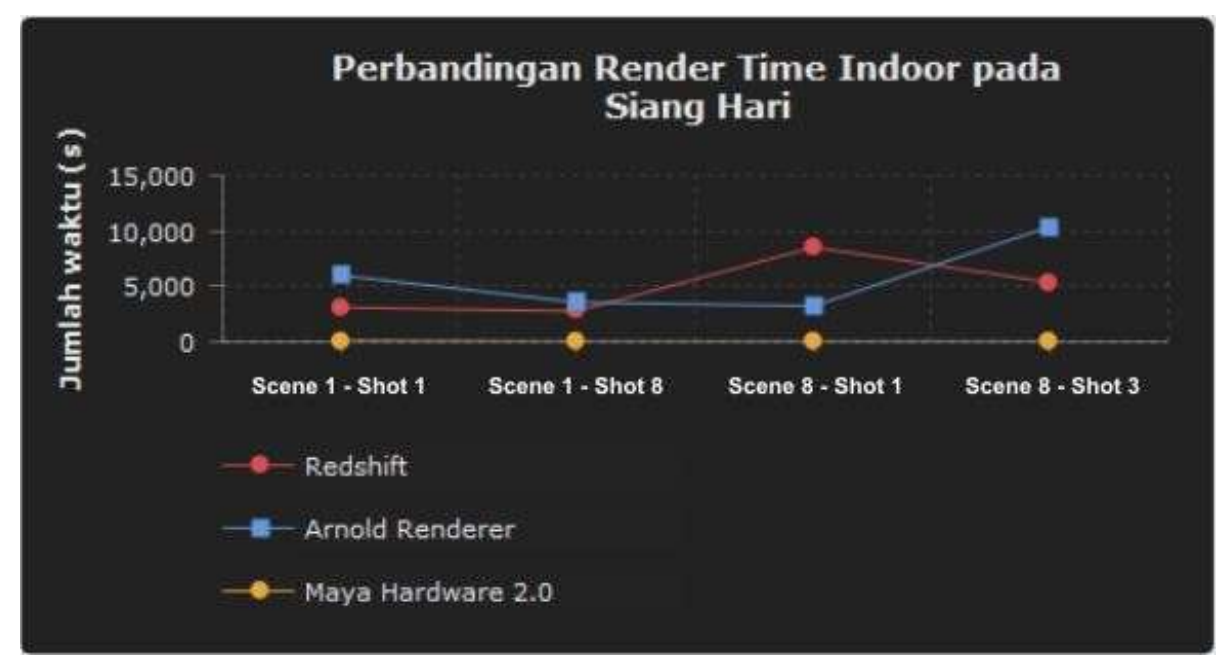

Gambar 1 Hasil grafik render time indoor pada siang hari

Dari grafik diatas dapat disimpukan bahwa perbandingan yang cukup signifikan antara Redshift, Arnold Renderer, dan Maya Hardware 2.0 dimana butuh waktu yang sangat lama untuk melakukan rendering menggunakan Redshift dan Arnold Renderer dibandingkan dengan Maya Hardware 2.0 dengan perbandingan rata-rata mencapai 133,3:156,2: 1 . 
Gambar 2 Hasil grafik render time outdoor pada siang hari

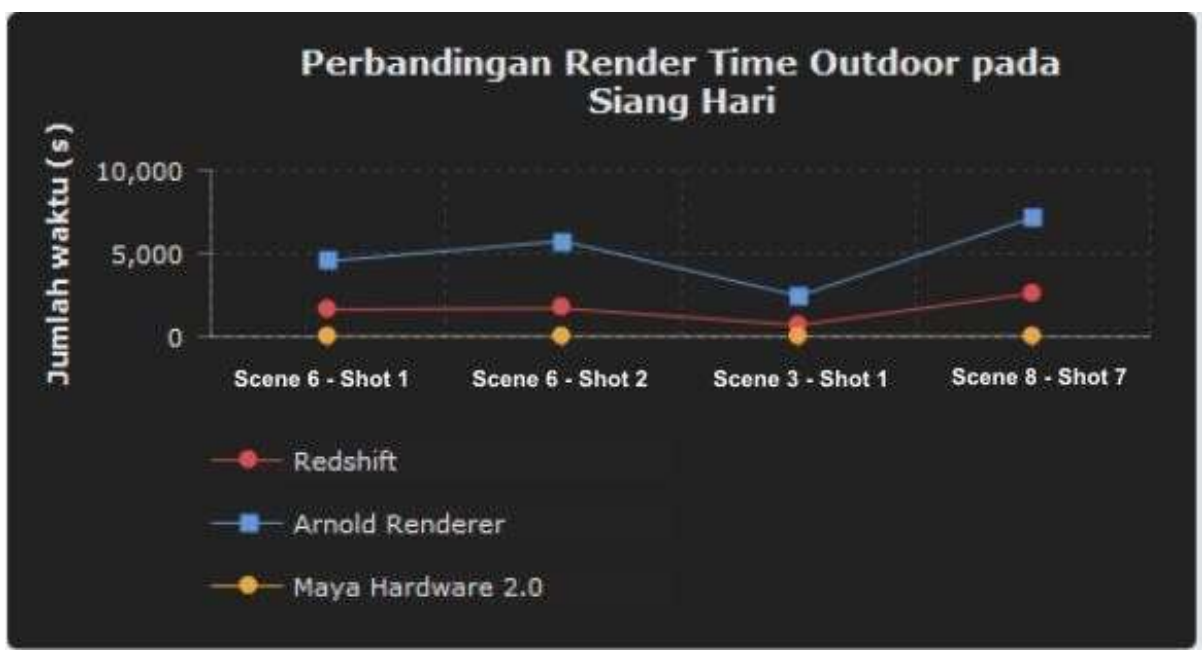

Dari grafik diatas dapat disimpukan bahwa perbandingan yang cukup signifikan antara Redshift, Arnold Renderer, dan Maya Hardware 2.0 dimana butuh waktu yang sangat lama untuk melakukan rendering menggunakan Redshift dan Arnold Renderer dibandingkan dengan Maya Hardware 2.0 dengan perbandingan rata-rata mencapai $87: 261,6: 1$.

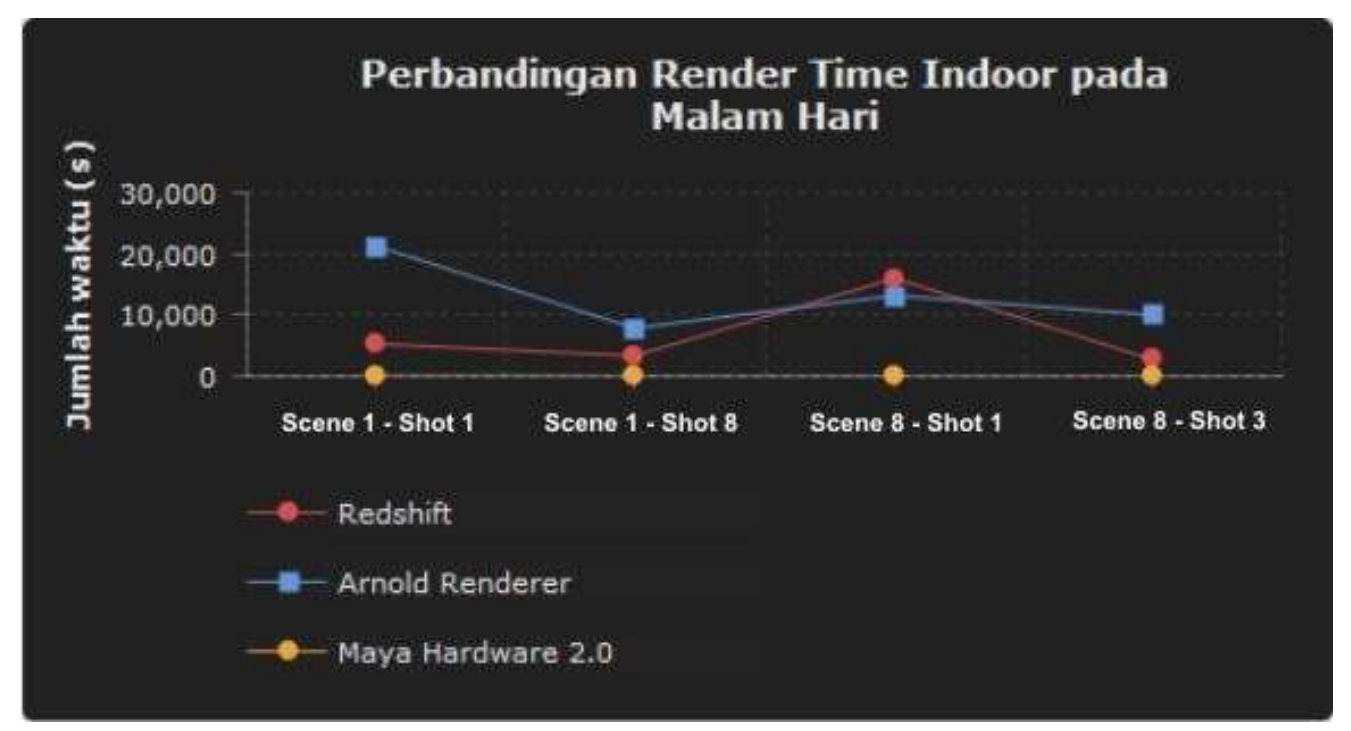

Gambar 3 Hasil grafik render time indoor pada malam hari

Dari grafik diatas dapat disimpukan bahwa perbandingan yang cukup signifikan antara Redshift, Arnold Renderer, dan Maya Hardware 2.0 dimana butuh waktu yang sangat lama untuk melakukan rendering menggunakan Redshift dan Arnold Renderer dibandingkan dengan Maya Hardware 2.0 dengan perbandingan rata-rata mencapai 189,4 : 363,2 : 1 . 


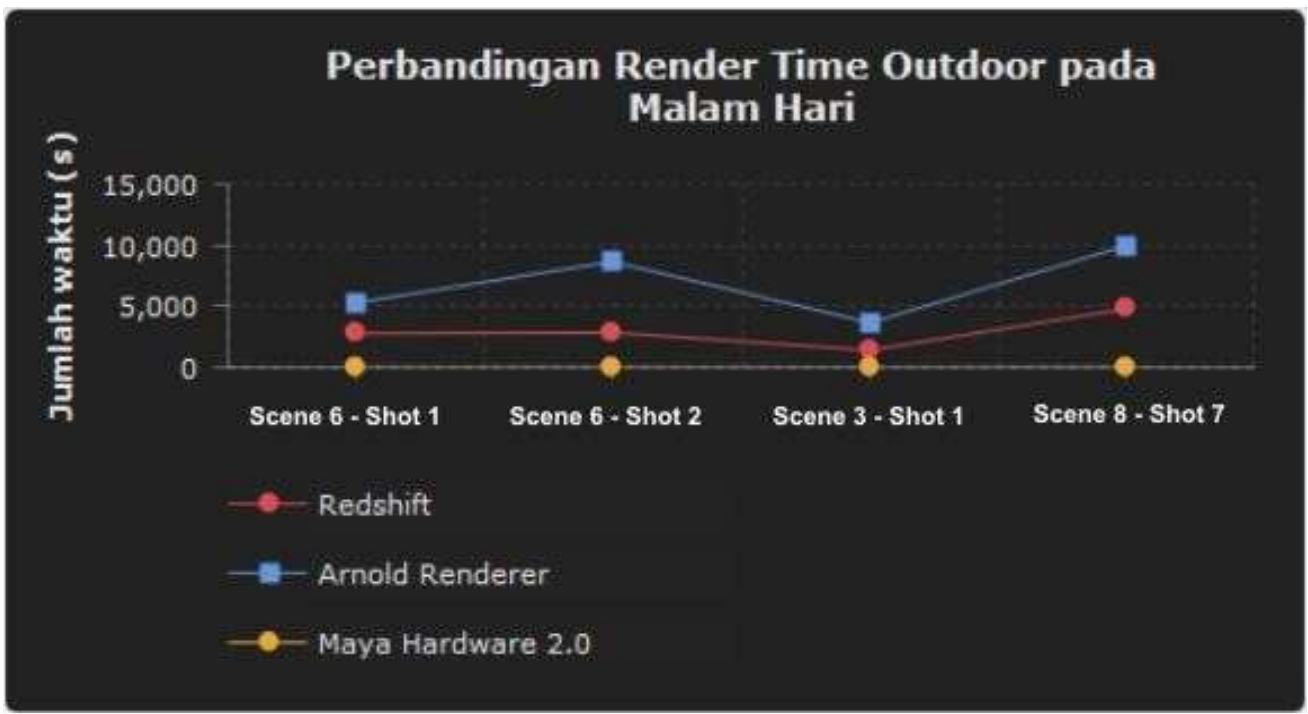

Gambar 4 Hasil grafik render time Outdoor pada malam hari

Dari grafik diatas dapat disimpukan bahwa perbandingan yang cukup signifikan antara Redshift, Arnold Renderer, dan Maya Hardware 2.0 dimana butuh waktu yang sangat lama untuk melakukan rendering menggunakan Redshift dan Arnold Renderer dibandingkan dengan Maya Hardware 2.0 dengan perbandingan rata-rata mencapai $155,4: 370,8: 1$.

Berikut hasil pengujian standar deviasi yang dibentuk dalam tabel statistik deskriptif seperti pada di bawah berikut. 
Tabel 1 Statistik deskriptif

\begin{tabular}{|l|c|c|c|c|c|c|}
\hline & N & Minimum & Maximum & Mean & Std. Deviation & Variance \\
\hline Redshift & 16 & 689 & 15990 & 4090.75 & 3006.36118 & 9038207.562 \\
\hline Arnold Renderer & 16 & 2447 & 10367 & 7719 & 3173.82796 & 10073183.937 \\
\hline Maya Hardware 2.0 & 16 & 9 & 87 & 27.75 & 20.42516 & 417.187 \\
\hline
\end{tabular}

1. Hasil Pengujian Kualitas Gambar

Berdasarkan kuesioner diatas terdapat 9 orang responden dimana tiap responden hanya diperlihatkan satu jenis engine render saja kemudian menjawab kedua pertanyaan diatas. Dengan melakukan kunjungan di PT. Kinema Systrans Multimedia sehingga di dapatlah jawaban dari masing masing kuesioner yang ahli di bidang rendering. Untuk hasil dari jawaban masing masing responden dapat dilihat pada tabel dibawah ini.

Tabel 2 Jawaban hasil render Redshift indoor

\begin{tabular}{|c|c|c|c|c|c|c|c|c|}
\hline Redshift & \multicolumn{4}{|c|}{ Hasil Render Redshift Siang Hari } & \multicolumn{4}{c|}{ Hasil Render Redshift Malam Hari } \\
\hline Responden & Soal 1 & Soal 2 & Soal 3 & Soal 4 & Soal 5 & Soal 6 & Soal 7 & Soal 8 \\
\hline 1 & 9 & 9 & 9 & 9 & 9 & 9 & 9 & 9 \\
\hline 2 & 8 & 8 & 8 & 8 & 6 & 6 & 6 & 6 \\
\hline 3 & 9 & 9 & 9 & 9 & 7 & 7 & 9 & 8 \\
\hline 4 & 6 & 7 & 6 & 5 & 6 & 6 & 5 & 7 \\
\hline 5 & 8 & 8 & 8 & 9 & 8 & 9 & 9 & 9 \\
\hline 6 & 9 & 9 & 9 & 9 & 9 & 9 & 9 & 9 \\
\hline 7 & 8 & 8 & 8 & 8 & 8 & 8 & 8 & 8 \\
\hline 8 & 6 & 7 & 8 & 8 & 7 & 7 & 6 & 6 \\
\hline 9 & 7 & 8 & 6 & 6 & 5 & 7 & 8 & 5 \\
\hline
\end{tabular}

Tabel 3 Jawaban hasil render Arnold Renderer indoor

\begin{tabular}{|c|c|c|c|c|c|c|c|c|}
\hline $\begin{array}{c}\text { Arnold } \\
\text { Renderer }\end{array}$ & \multicolumn{2}{|c|}{ Hasil Render Arnold Renderer Siang } & \multicolumn{4}{c|}{ Hasil Render Arnold Renderer Malam } \\
Hari
\end{tabular}




\begin{tabular}{|l|l|l|l|l|l|l|l|l|}
\hline 2 & 2 & 2 & 2 & 2 & 2 & 2 & 2 & 2 \\
\hline 3 & 6 & 5 & 7 & 6 & 7 & 6 & 8 & 8 \\
\hline 4 & 6 & 7 & 6 & 5 & 7 & 6 & 5 & 6 \\
\hline 5 & 6 & 3 & 3 & 3 & 3 & 3 & 3 & 3 \\
\hline 6 & 5 & 5 & 5 & 5 & 5 & 5 & 5 & 5 \\
\hline 7 & 5 & 5 & 5 & 5 & 5 & 5 & 6 & 6 \\
\hline 8 & 3 & 2 & 3 & 2 & 4 & 2 & 5 & 5 \\
\hline 9 & 5 & 5 & 4 & 3 & 4 & 3 & 4 & 4 \\
\hline
\end{tabular}

Tabel 4 Jawaban hasil render Arnold Renderer indoor

\begin{tabular}{|c|c|c|c|c|c|c|c|c|}
\hline $\begin{array}{c}\text { Maya } \\
\text { Hardware } \\
\mathbf{2 . 0}\end{array}$ & \multicolumn{4}{|c|}{$\begin{array}{c}\text { Hasil Render Maya Hardware 2.0 } \\
\text { Siang Hari }\end{array}$} & \multicolumn{5}{c|}{ Hasil Render Maya Hardware 2.0 } \\
\hline Ralam Hari \\
\hline Responden & Soal 17 & Soal 18 & Soal 19 & Soal 20 & Soal 21 & Soal 22 & Soal 23 & $\begin{array}{c}\text { Soal } \\
24\end{array}$ \\
\hline 1 & 7 & 7 & 7 & 7 & 7 & 7 & 7 & 7 \\
\hline 2 & 6 & 6 & 6 & 6 & 6 & 6 & 6 & 6 \\
\hline 3 & 9 & 9 & 9 & 8 & 7 & 6 & 8 & 8 \\
\hline 4 & 6 & 6 & 5 & 7 & 5 & 7 & 5 & 6 \\
\hline 5 & 4 & 4 & 4 & 4 & 5 & 5 & 5 & 5 \\
\hline 6 & 1 & 1 & 1 & 1 & 1 & 1 & 1 & 1 \\
\hline 7 & 6 & 6 & 6 & 6 & 6 & 6 & 6 & 6 \\
\hline 8 & 7 & 7 & 6 & 6 & 7 & 6 & 6 & 7 \\
\hline 9 & 6 & 6 & 5 & 3 & 4 & 3 & 3 & 3 \\
\hline
\end{tabular}

Tabel 5 Jawaban hasil render Redshift outdoor

\begin{tabular}{|c|c|c|c|c|c|c|c|c|}
\hline Redshift & \multicolumn{3}{|c|}{ Hasil Render Redshift Siang Hari } & \multicolumn{4}{|c|}{ Hasil Render Redshift Malam Hari } \\
\hline Responden & Soal 25 & Soal 26 & Soal 27 & Soal 28 & Soal 29 & Soal 30 & Soal 31 & $\begin{array}{c}\text { Soal } \\
32\end{array}$ \\
\hline 1 & 10 & 10 & 10 & 10 & 10 & 10 & 10 & 10 \\
\hline 2 & 8 & 8 & 8 & 8 & 8 & 8 & 8 & 8 \\
\hline 3 & 7 & 8 & 7 & 8 & 10 & 10 & 10 & 10 \\
\hline 4 & 5 & 6 & 7 & 6 & 5 & 6 & 7 & 5 \\
\hline 5 & 8 & 8 & 8 & 8 & 8 & 8 & 8 & 8 \\
\hline 6 & 9 & 9 & 9 & 9 & 9 & 9 & 9 & 9 \\
\hline 7 & 8 & 8 & 8 & 8 & 8 & 8 & 8 & 8 \\
\hline 8 & 8 & 8 & 7 & 6 & 7 & 6 & 6 & 6 \\
\hline 9 & 8 & 6 & 5 & 5 & 6 & 7 & 6 & 6 \\
\hline
\end{tabular}


Tabel 6 Jawaban hasil render Arnold Renderer outdoor

\begin{tabular}{|c|c|c|c|c|c|c|c|c|}
\hline $\begin{array}{c}\text { Arnold } \\
\text { Renderer }\end{array}$ & \multicolumn{6}{|c|}{ Hasil Render Arnold Renderer Siang } & \multicolumn{3}{c|}{ Hasil Render Arnold Renderer Malam } \\
\hline Responden & Soal 33 & Soal 34 & Soal 35 & Soal 36 & Soal 37 & Soal 38 & Soal 39 & $\begin{array}{c}\text { Soal } \\
40\end{array}$ \\
\hline 1 & 5 & 5 & 5 & 5 & 9 & 6 & 6 & 5 \\
\hline 2 & 2 & 2 & 2 & 2 & 2 & 2 & 2 & 2 \\
\hline 3 & 7 & 7 & 7 & 7 & 8 & 7 & 7 & 7 \\
\hline 4 & 7 & 6 & 5 & 7 & 5 & 7 & 5 & 6 \\
\hline 5 & 5 & 5 & 5 & 5 & 7 & 7 & 7 & 7 \\
\hline 6 & 5 & 5 & 5 & 5 & 5 & 5 & 5 & 5 \\
\hline 7 & 5 & 5 & 5 & 5 & 6 & 6 & 6 & 6 \\
\hline 8 & 3 & 3 & 2 & 3 & 5 & 4 & 4 & 3 \\
\hline 9 & 6 & 4 & 5 & 5 & 6 & 4 & 4 & 4 \\
\hline
\end{tabular}

Tabel 7 Jawaban hasil render Maya Hardware 2.0 outdoor

\begin{tabular}{|c|c|c|c|c|c|c|c|c|}
\hline $\begin{array}{c}\text { Maya } \\
\begin{array}{c}\text { Hardware } \\
\mathbf{2 . 0}\end{array}\end{array}$ & \multicolumn{9}{|c|}{$\begin{array}{c}\text { Hasil Render Maya Hardware 2.0 } \\
\text { Malam Hari }\end{array}$} \\
\hline $\begin{array}{c}\text { Responden } \\
\text { Siang Hari }\end{array}$ & Soal 41 & Soal 42 & Soal 43 & Soal 44 & Soal 45 & Soal 46 & Soal 47 & $\begin{array}{c}\text { Soal } \\
48\end{array}$ \\
\hline 1 & 8 & 8 & 8 & 8 & 7 & 7 & 7 & 7 \\
\hline 2 & 6 & 6 & 6 & 6 & 5 & 5 & 5 & 5 \\
\hline 3 & 7 & 8 & 8 & 8 & 7 & 7 & 7 & 9 \\
\hline 4 & 7 & 6 & 5 & 7 & 6 & 5 & 7 & 6 \\
\hline 5 & 7 & 7 & 7 & 7 & 7 & 7 & 7 & 7 \\
\hline 6 & 1 & 1 & 1 & 1 & 1 & 1 & 1 & 1 \\
\hline 7 & 7 & 7 & 7 & 7 & 6 & 6 & 6 & 7 \\
\hline 8 & 7 & 8 & 7 & 8 & 7 & 7 & 6 & 6 \\
\hline 9 & 7 & 7 & 7 & 7 & 4 & 6 & 4 & 4 \\
\hline
\end{tabular}


Berdasarkan data kuesioner diatas, kualitas hasil render menggunakan Redshift, Arnold Renderer, Maya Hardware 2.0 dapat dikonversikan menjadi tabel grafik sehingga menjadi seperti pada gambar berikut.

JAMN Vol. x, No. x, Maret 201x: xx - xx 


\section{Perbandingan Kualitas Hasil Render Indoor pada Siang Hari}

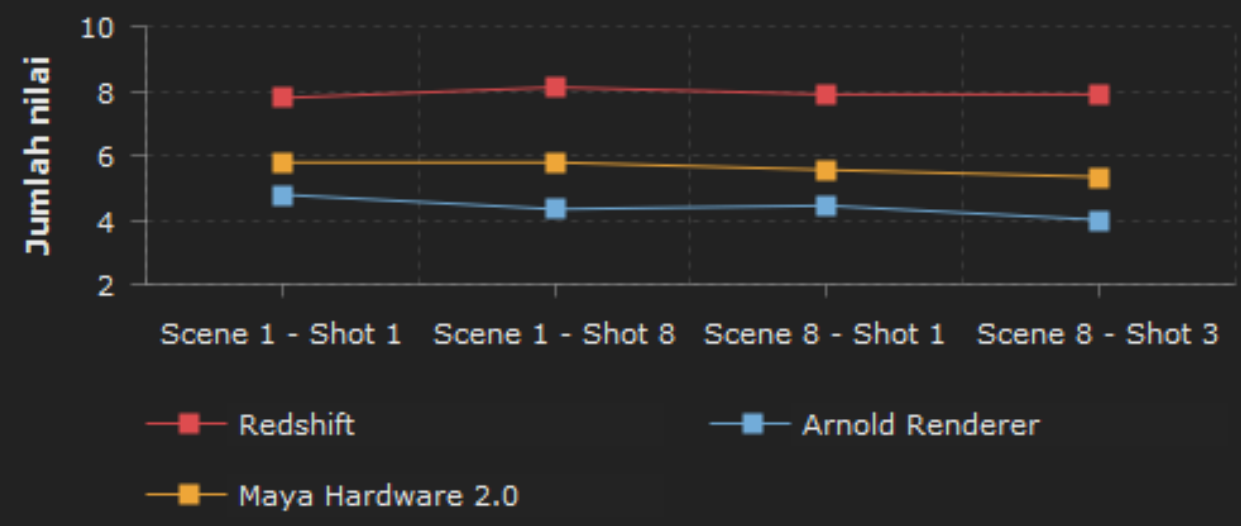

Gambar 5 Hasil grafik kualitas render indoor pada siang har

Pada indoor siang hari, berdasarkan gambar diatas dapat dilihat bahwa rata-rata tertinggi kualitas gambar yang dihasilkan oleh engine render Redshift sebesar 8.11, kualitas rata-rata tertinggi yang dihasilkan oleh Arnold Renderer adalah sebesar 4.78, sedangkan rata-rata tertinggi yang dihasilkan oleh Maya Hardware 2.0 adalah sebesar 5.78.

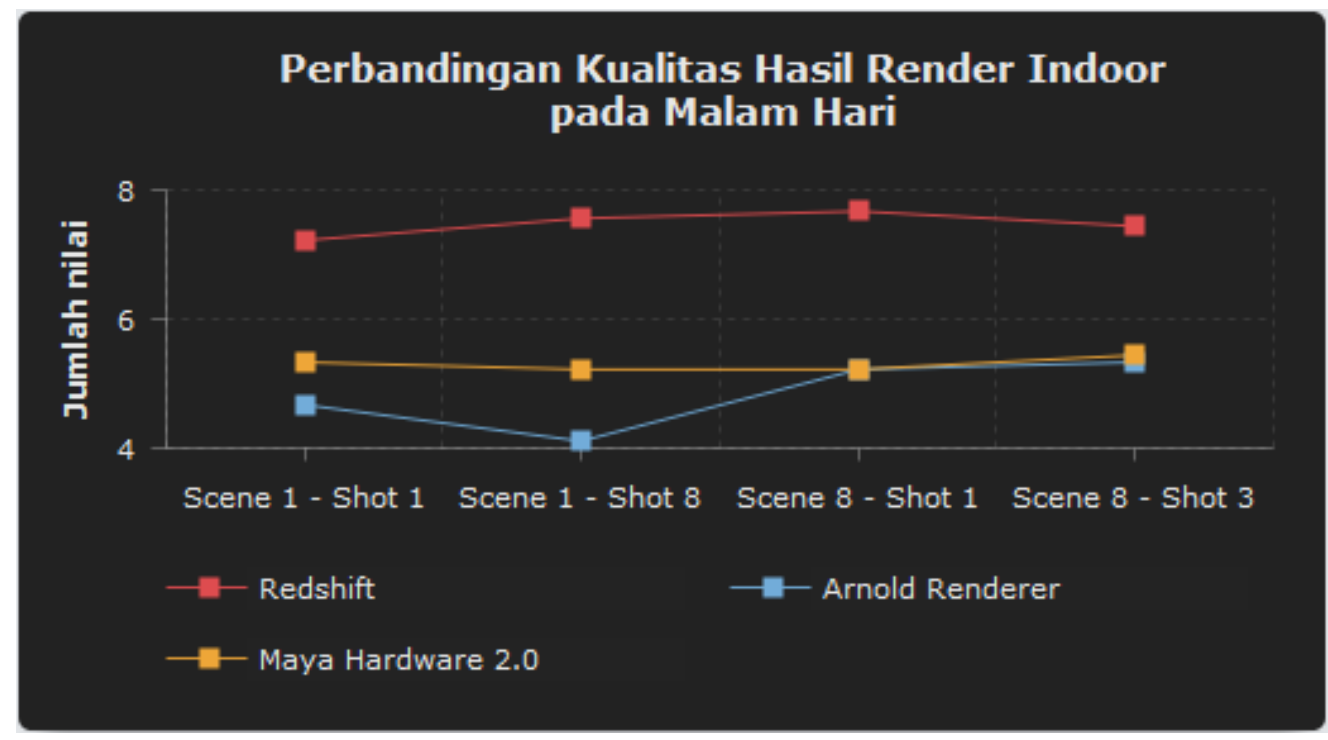

Gambar 6 Hasil grafik kualitas render indoor pada siang hari

Pada indoor malam hari, berdasarkan gambar diatas dapat dilihat bahwa rata-rata tertinggi kualitas gambar yang dihasilkan oleh engine render Redshift sebesar 7.67, kualitas rata-rata tertinggi yang dihasilkan oleh Arnold Renderer adalah sebesar 5.33, sedangkan rata-rata tertinggi yang dihasilkan oleh Maya Hardware 2.0 adalah sebesar 5.44. 


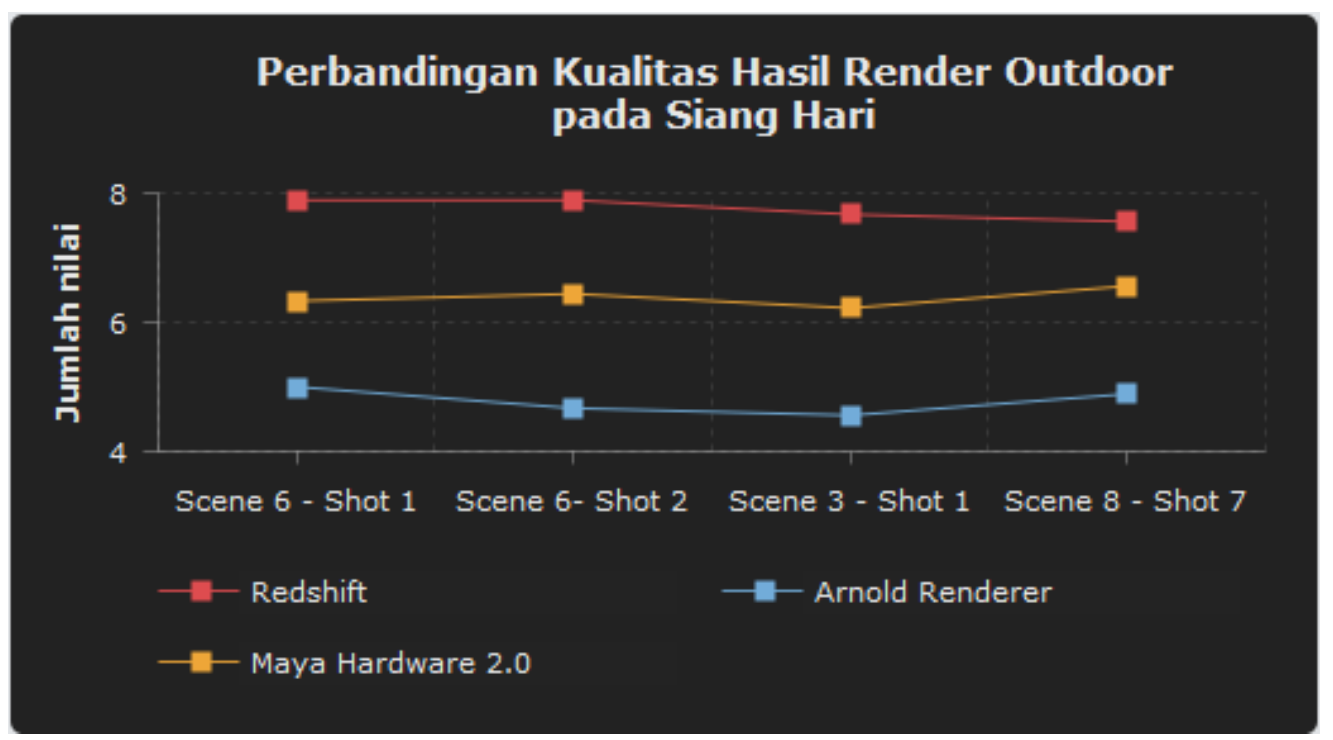

Gambar 7 Hasil grafik kualitas render indoor pada siang hari

Pada outdoor siang hari, berdasarkan gambar diatas dapat dilihat bahwa rata-rata tertinggi kualitas gambar yang dihasilkan oleh engine render Redshift sebesar 7.89, kualitas rata-rata tertinggi yang dihasilkan oleh Arnold Renderer adalah sebesar 5, sedangkan rata-rata tertinggi yang dihasilkan oleh Maya Hardware 2.0 adalah sebesar 6.56.

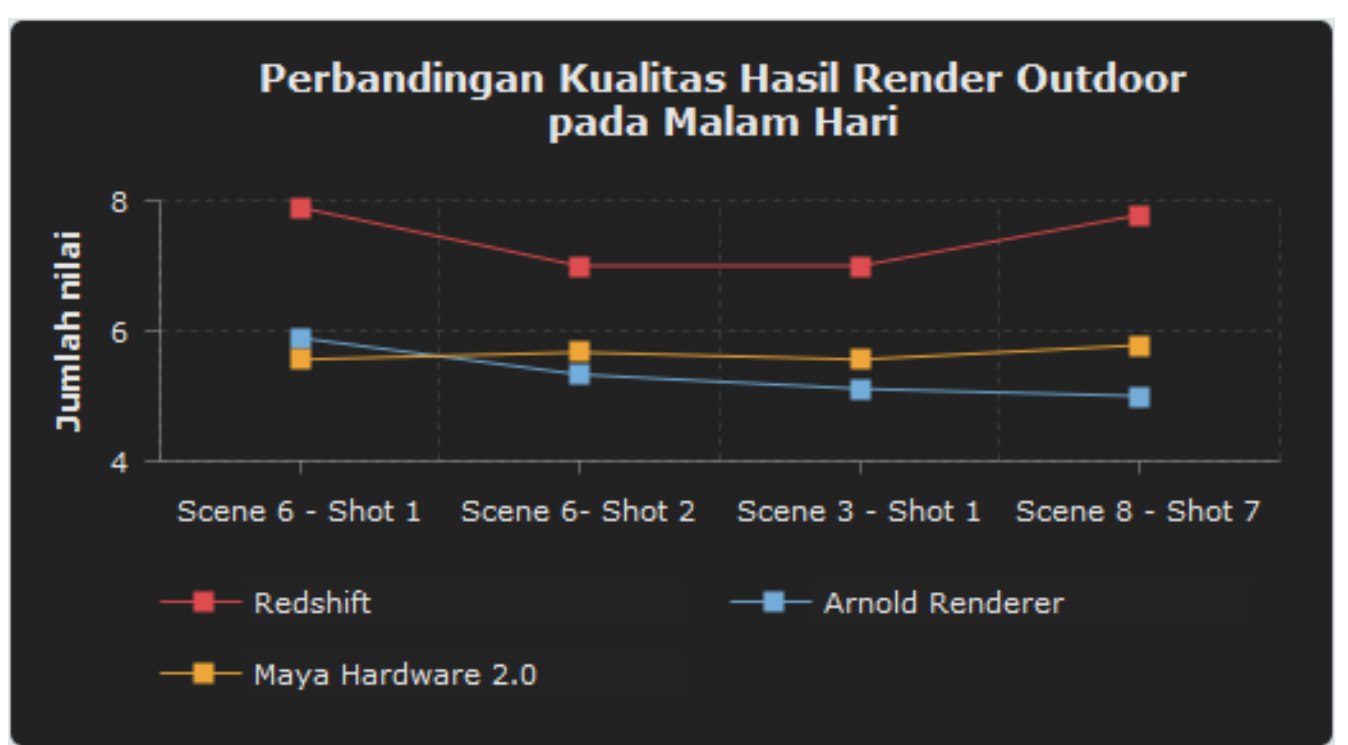

Gambar 8 Hasil grafik kualitas render indoor pada siang hari

Pada outdoor malam hari, berdasarkan gambar diatas dapat dilihat bahwa rata-rata tertinggi kualitas gambar yang dihasilkan oleh engine render Redshift sebesar 8, kualitas rata-rata tertinggi yang dihasilkan oleh Arnold Renderer adalah sebesar 5.89, sedangkan rata-rata tertinggi yang dihasilkan oleh Maya Hardware 2.0 adalah sebesar 5.78. 


\section{RATA-RATA HASIL KESELURUHAN}

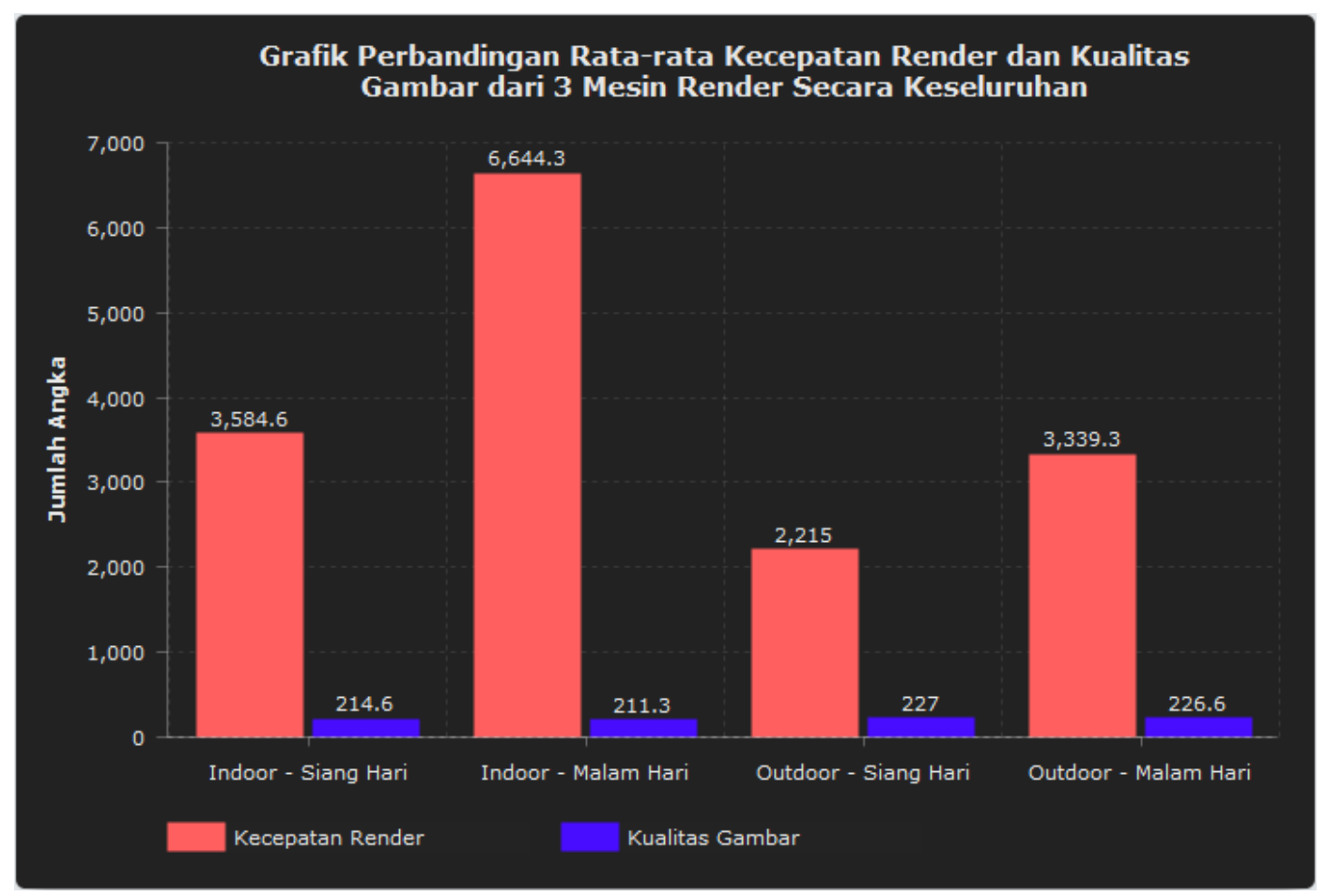

Gambar 9 Hasil grafik rata-rata baik kecepatan render maupun kualitas gambar secara

keseluruhan

Berdasarkan gambar grafik diatas dapat dilihat bahwa rata-rata perbandingan kecepatan render dari semua mesin render pada indoor, outdoor, siang dan malam adalah 3.584,6 : 6.644,3 : 2.215 : 3.339,3. Sedangkan kualitas gambar yang dihasilkan dari semua mesin render pada indoor, outdoor, siang dan malam adalah 214,6 : 211,3 : 227 : 226,6. Berikut adalah hasil render dari tiap render engine:

\section{KESIMPULAN}

Adapun kesimpulan yang diperoleh dari pengujian serta analisis yang telah dilakukan adalah berikut :

1) Dengan merender film animasi "Telat" diketahui untuk waktu render tercepat adalah engine render Maya Hardware 2.0 dengan waktu rata-rata sebesar 9 detik. Sedangkan Waktu render terlama adalah render engine Arnold Renderer dengan waktu rata-rata sebesar 21258 detik.

2) Analisis kualitas noise pada hasil render :

a. Untuk kualitas noise yang terbaik pada kondisi siang indoor berdasarkan hasil dari data kuesioner dengan membandingkan hasil kualitas noise pada film animasi 3D yang berjudul "Telat" dengan Serial Animasi 3D yang berjudul "Ollie and Friends Season 5" yaitu mesin render Redshift dengan nilai yang didapat dari rata-rata keseluruhan hasil kuesioner sebesar "8.11".

b. Untuk kualitas noise yang terbaik pada kondisi malam indoor berdasarkan hasil dari data kuesioner dengan membandingkan hasil kualitas noise pada film animasi 3D yang berjudul "Telat" dengan Serial Animasi 3D yang berjudul "Ollie and Friends Season 5" yaitu mesin render Redshift dengan nilai yang didapat dari rata-rata keseluruhan hasil kuesioner sebesar "7.67". 
c. Untuk kualitas noise yang terbaik pada kondisi siang outdoor berdasarkan hasil dari data kuesioner dengan membandingkan hasil kualitas noise pada film animasi 3D yang berjudul "Telat" dengan Serial Animasi 3D yang berjudul "Ollie and Friends Season 5" yaitu mesin render Redshift dengan nilai yang didapat dari rata-rata keseluruhan hasil kuesioner sebesar "7.89".

d. Untuk kualitas noise yang terbaik pada kondisi malam outdoor berdasarkan hasil dari data kuesioner dengan membandingkan hasil kualitas noise pada film animasi 3D yang berjudul "Telat" dengan Serial Animasi 3D yang berjudul "Ollie and Friends Season 5" yaitu mesin render Redshift dengan nilai yang didapat dari rata-rata keseluruhan hasil kuesioner sebesar "8".

e. Analisis yang didapatkan dari merender Film animasi 3D yang berjudul "Telat" dengan membandingkan pada serial animasi 3D yang berjudul "Ollie and Friends season 5", mesin render Redshift menghasilkan kualitas noise yang paling bagus pada semua kondisi rata rata namun membutuhkan waktu render yang lama. Untuk mesin render Maya Hardware 2.0 menghasilkan waktu render yang lebih cepat namun kualitas noise pada gambar berkurang. Jadi untuk menghasilkan kualitas noise yang bagus diperlukan waktu render yang cukup lama.

\section{DAFTAR PUSTAKA}

[1] Ade Winata, Heru, dkk (2015), Perancangan Animasi 3D Jati Diri si Kacang, Politeknik Negeri Batam.

[2] Amy, Rizqi (2013)., Analisis Dan Perancangan 3d Modeling Kapal Dengan Menggunakan Autodesk Maya, Sekolah Tinggi Manajemen Informatika dan Komputer Amikom, Yogyakarta.

[3] Dwiperdana., 2013, Low poly vs High Poly 3D Model, Institut Kesenian Jakarta.

[4] Florentina, Ega (2016)., Analisis Similaritas Hasil Render Pada Scene Murni Animasi Dan Hasil Animasi Pada Tahap Compositing Politeknik Negeri Batam.

[5] Gay, L.R. dan Diehl, P.L. (1992), Research Methods for Business and. Management, MacMillan Publishing Company, New York.

[6] Hendriyanto, Kurniawan Widi (2013)., Perancangan Video Promosi Dengan Menggunakan Teknik 3D Modeling Low Poly, Program Studi DKV, Universitas Kristen Satya Wacana.

[7] Joharudin, Aji., 2015, Analisis hasil rendering Autodesk maya 2013 pada film Animasi 3D Fighter of Egrang, Amikom Yogyakarta. 